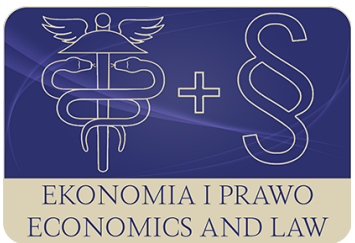

EKONOMIA I PRAWO. ECONOMICS AND LAW

Volume 19, Issue 4, December 2020

p-ISSN 1898-2255, e-ISSN 2392-1625

www.economicsandlaw.pl

EKONOMIA I PRAWO

ORIGINAL ARTICLE

received 30.03.2019; revised 12.02.2020; accepted 31.12.2020

Citation: Głód, G. (2020). The competitiveness of a public hospital in Poland in the light of changing regulations in the health care sector. Ekonomia i Prawo. Economics and Law, 19(4): 657-672. doi:10.12775/EiP.2020.043.

\title{
The competitiveness of a public hospital in Poland in the light of changing regulations in the health care sector
}

\author{
GRZEGORZ GEÓD \\ University of Economics in Katowice, College of Economics, Department of Entrepreneurship \\ and Innovation Management, ul. 1 Maja 50, 40-287 Katowice, Poland \\ घrzegorz.glod@ue.katowice.pl \\ (D) orcid.org/0000-0001-9699-2427
}

\begin{abstract}
Motivation: The health care sector in Poland is undergoing a continuous restructuring process that directly affects the functioning of treatment entities, especially hospitals. One of the key changes is the introduction of a system of basic hospital security of health care services. In this context, the question arises about the competitive management of a public hospital in Poland and the use of entrepreneurial management tools and the possible scope of these processes in the current external conditions. The aim of these efforts is to increase the efficiency of the health care sector, better tailor services to social needs, and improve the management of limited resources.
\end{abstract}

Aim: The aim of the article is to assess the possibility of increasing public hospital competitiveness in Poland in the context of new regulations in the health care sector. These regulations concern the method of contracting health services, the rules for admission to their performance and flat-rate financing. The analysis will be carried out based on the analysis of legal acts and using the elements of the integrated enterprise competitiveness model by

G. Głód and O. Flak.

Results: Formulating recommendations for public hospital managers in the field of raising competitiveness and indicating the possibility of using appropriately adapted tools to assess the competitiveness in the private sector for entities operating in the public sector.

Keywords: management in a health care entity; competitiveness; public management; public entrepreneurship; hospital

JEL: I11; I19; L32 


\section{Introduction}

Faced with the turbulent external environment characterized by fast advancing technologies and increasingly varying needs of public service recipients, the public sector requires changes improving its functioning. The measures adopted in this area may lead to generating alternative revenues, improving internal processes and developing innovative solutions aimed to meet social and economic needs. The issue seems to be of even more pressing nature in the light of the strategic importance of medical services to every human being, each patient's desire for an immediate resolution of every problem, coupled with demographic changes, which means it is practically impossible to provide a conclusive solution to such a need. This is mainly due to limited resources available within the health care sector, but also, indirectly, to the management of these resources, which is not optimal. These problems become particularly evident in the Polish public health care, which is undergoing a process of constant changes. Accordingly, not only threats need to be counteracted, but opportunities emerging in the environment of health care units must be identified and grasped. The aim of these efforts is to increase the efficiency of the health care sector, tailor services to social needs, and improve the management of limited resources.

In this context, the concept of the competitiveness of a public hospital seems to be relatively risky, while even the mere juxtaposition of the words is partially mutually exclusive.

The considerations presented above prompted the author to undertake an attempt to assess the competitiveness of a public hospital in Poland, which operates in a specific environment and, particularly, in a specific legal environment. In order to achieve this, he applied the methodology successfully used in the commercial sector. The main purpose of the research was to assess the model operationalization used for research purposes and the competitiveness of the public hospital in Poland.

The study relates to the author's research interests in the competitiveness of enterprises (Flak \& Glód, 2012), the functioning of health care entities in the aspect of public entrepreneurship (Gtód, 2016), and practical experience originating in the implementation of a number of consultancy projects in the health care sector.

\section{Competition in the public health care}

The study focused on the health care sector (in particular the public hospital), which is characterized by market orientation in part of its public activity and, to a significant extent, remains subject to market competition. According to public management areas identified by Kożuch (2004, p. 60), the health care sector can be included in the sphere of public health management and management of primary level organizations. Public health care entities belong to public sector 
entities (state and local government subsectors) and - pursuant to the Public Finance Act — to the public finance sector (Ziębicki, 2014, p. 109, 114).

On the one hand, this choice stems from the importance of public health care and, on the other hand, problems related to its organization and financing, which is revealed in the constantly recurring question on how to cure health care (Goodman et al., 2008). The main source of problems in the health care system lies primarily in the limited financial resources available within the system, but its efficiency is also indirectly affected by the management of these resources, which is not entirely effective. These problems are particularly evident in the functioning of Polish public health care, undergoing a process of constant changes. In this context, the question arises about the impact of measures improving competitiveness at the individual and organizational level on the performance of public health care organizations in Poland.

The concept of hospital competitiveness appears relatively often in a variety of contexts in literature. It is used when attempts are made to determine the competitive position of a hospital using benchmarking. Benchmarking builds the understanding of the competitive position of a hospital compared to other entities, indicates the directions of strategic actions, identifies development potential and helps select or review the goals pursued by the hospital (Kanownik, 2014, p. 566; Macuda, 2015). In this area, there are studies on competitiveness within medical clusters (Li \& Xia, 2013; Romaniuk et al., 2016). The concept also appears in the context of recommendations aiming to improve hospital competitiveness (Barros \& de Jesus Pacheco, 2016; Bielicki \& Ciesielski, 2012; Lu \& Wang, 2008; Majchrzak-Lepszyk \& Bober, 2016).

The concept of enterprise competitiveness, on the other hand, can be perceived from two angles: static - as a certain state reflecting an enterprise's potential compared to competitors: it is measured by market share (performance competitiveness), and dynamic - as an enterprise's capacity for using its own potential and external conditions to respond to market changes, as well as to create these changes and improve its current position against competitors (factor competitiveness) (Olszewska \& Piwoni-Krzeszowska, 2004). In this context, the question arises whether such an approach can be directly applied to a public hospital. A positive answer can relate to the argument that competition must also apply to this sector of the economy, if only because of the challenges currently facing health care worldwide, such as the increasing elderly population, growing costs related to health care technologies, and rising patient expectations. These challenges require effective allocation of financial and scarce resources in health care (Kanownik, 2014, p. 560).

Porter (2007) argues that effective competition and efficiency in health care in every country occur when the following premises exist: health care entities focus on creating value for patients, not only on reducing costs, a universal method is used to measure the effects and costs of the treatment of each patient, health care institutions take into account the whole cycle of patient care (long-term approach), competition exists on a local, regional and national level, 
treatment outcomes and the operations of health care entities are measured and reported; at the same time, universal access to information for all stakeholders in the health care system is ensured, innovative activities that aim to increase value for patients are rewarded, the integration of health care is underway (Kanownik, 2014, p. 560).

Accordingly, the definition of competitiveness as a concept evaluating entities participating in competition from the point of view of their performance and ability to achieve benefits in the future changing competitive environment seems accurate and 'competitiveness' integrates marketing and investment evaluation. An entity is competitive when it creates added value in business activity that allows, on the one hand, to increase its commercial attractiveness necessary to capture market share, while, on the other hand, it ensures profitability and accumulation, enabling above-average growth. If an enterprise achieves growth from sales and strengthens its market position, but it does not derive benefits ensuring the adequate level of accumulation and investment, it is uncompetitive (Bossak \& Bieńkowski, 2004, pp. 18-19).

The concept of competitiveness is also used to determine the relationship between an enterprise's characteristics and the characteristics of its competitors, resulting from many internal features and ability to deal with external conditions. Therefore, the competitiveness of an enterprise expresses its agility in relation to innovative and efficient use of resources in value creation processes, primarily for customers, but also for other interest groups (e.g. management, shareholders, potential investors) (Urbanowska-Sojkin et al., 2004, pp. 271-272). While evaluating the competitiveness of a public hospital, it is important to adopt the approach taking into account relations with stakeholders (Eiriz et al., 2010). In their presentation of the hospital competitiveness assessment model, Eiriz et al. (2010) identify three main areas: organization (form of ownership, organizational complexity, resources); strategic behaviors (relations with stakeholders, the scope of services provided, connections with other hospitals) and performance (performance indicators, efficiency and effectiveness, benchmarking). The core of competitive advantage is the way in which added value is created using resource configurations (which the organization develops), the types of economic activity (in which the organization competes), and management infrastructure (which drives the organization) (Bratnicki, 2000, p. 58).

According to the benchmarking approach, on the other hand, competitiveness can be treated as a measure of the aggregate capacity for competition with other firms to achieve or maintain a particular competitive position, in terms of market, financial, technical and organizational criteria. An enterprise's competitive position is defined as its place on the ranking of enterprises operating in a given sector, based on quantitative and qualitative diagnostic criteria (Stabryła, 2000, pp. 66-67). Such an approach is relatively typical of the health care sector due to numerous hospital rankings, but it is also complicated, because it is necessary to determine what economic and medical information is 
needed in the integrated evaluation system of public hospital performance using selected groups of indicators and measures (Hass-Symotiuk, 2011).

\section{Methods}

The aim of the empirical study was to identify opportunities for increasing the competitiveness of public hospitals in Poland under current legislation. At the same time, there was made an assessment of the approach used in the commercial sector to the conditions of the public hospital. This approach presents the stage of preparing for further research in this sector with the adaptation of the selected research procedure.

The study comprised:

- Regulation of the Minister of Health amending the regulation on the method of determining the flat-rate system of the basic hospital provision of health care services (2018);

- Regulation of the Minister of Health on specific criteria for the selection of tenders in proceedings on the conclusion of contracts for the provision of health care services (2016);

- Announcement of the Minister of Health on the codification of the Regulation of the Minister of Health on the cover guaranteed in the area of hospital treatment (2017).

In order to present a specific case study, legal regulations were referred to hospital treatment services in the field of vascular surgery. This choice was caused by the high level of reference of this group of medical services and the existence of competition in this respect between entities providing these services. In addition, it should be emphasized that there are quite large entry barriers in this area.

Then an attempt was made to assess to what extent the conditions in which public hospitals operate corresponded to the elements of the integrated model of enterprise competitiveness, developed by O. Flak and G. Głód. The assumptions of the model are characterized below.

The literature review combined with the author's research experience in the analysis of company competitiveness enabled the identification of the most important scope of interests and definitions within the integrated model of competitiveness. The model consists of 5 elements (Flak \& Głód, 2012, p. 57).

The first element is competitive potential, which consists of resources which a company owns or should own and which can be used to create or maintain its ability to compete. It refers to all of the enterprise capabilities resulting from its tangible and intangible assets. Competitive potential of a company is, at the same time, a relative multi-faceted concept.

The second element is competitive strategy. It is a plan adopted by a company with the intention to gain competitive advantage over other business entities operating in the external environment in order to meet an enterprise's prime goals and objectives. 
The third element is competitive advantage which is defined as the ability of an enterprise to deliver material and immaterial values to its customers through the market. Competitive advantage is a relative multi-faceted concept.

The fourth is competitive positioning, understood as market and economic outcomes of an enterprise. These outcomes depend on the extent to which the abilities to compete have been or will be used.

What influences enterprise competitiveness is the business environment. In the integrated model of company competitiveness, the business environment is referred to as a competitive platform and it involves the characteristics of the environment which surrounds an enterprise in a given sector. The characteristics of the macro environment are the same for every enterprise operating in a given sector.

Scheme 1 presents the visual representation and the situational context that enables competition. Each element of the integrated competitiveness model has been subjected to detailed analysis of the public hospital's competitiveness analysis in the field of vascular surgery medical services.

Accordingly, the following question can be addressed: can the competitiveness model used in research into private sector enterprises be applied to assess the competitiveness of a public hospital? In addition, the conducted research is to identify determinants affecting the improvement or deterioration of the competitiveness of a public hospital.

\section{Results}

The first stage of the study involved the analysis of formal requirements related to the provision of services by a hospital in the indicated area (vascular surgery).

Table 1 presents selected detailed requirements for the provision of services in the field of vascular surgery. They constitute a prerequisite for conducting activity in this area. These are minimum requirements that need to be met by a hospital and, in terms of strategic analysis, they can be defined as barriers to entry into this segment of health care services in the primary and secondary referral levels.

Table 2 presents the criteria for the selection of tenders in the proceedings on the conclusion of contracts for the provision of health care services in the field of vascular surgery. The evaluation of the criteria takes place within a competition procedure held by the public payer in Poland, i.e. the National Health Fund. The criteria embrace some competitiveness related aspects with regard to entities applying for a contract and ultimately rank those entities based on their competitiveness.

It should be added that in the case of the evaluation of vascular surgery services at the secondary referral level, the criteria are more stringent. For example, a minimum of $75 \%$ of the procedures (ICD-9) in the preceding year and the treatment of a minimum of $75 \%$ of the procedures (ICD-9) in the last 
12 months are required. Additional points are awarded for the completion of the contract in the field of chest surgery in the outpatient hospital clinic.

The formula for calculating the value of a contract contains three variables: a projected price of a reporting unit, which is determined separately in the purchase plan by each regional branch of the National Health Fund (NFZ), the adjusted number of reporting units, and a qualitative correction factor Q. Bonus points are awarded for the performance of more outpatient services and for quality assurance certificates The $\mathrm{Q}$ factor increases by 0.01 , if an entity provides $10 \%$ more health check in a hospital outpatient clinic. The index grows by 0.015 for hospitals classified as operating on a national basis and at the tertiary referral level, if the average value of hospitalization increases by $3 \%$. The index also increases by 0.02 , if a hospital is accredited by the Quality Monitoring Center with the result of $90 \%$, by 0.015 when the result is above $80 \%$, and by 0.01 if it is lower. The coefficient increases by 0.005 if a hospital's microbiological laboratory holds the Polmicro National Certificate of Microbiological Testing Credibility or participates in an inter-laboratory quality assessment program for clinical chemistry, run by the National Center for Laboratory Diagnostics Quality Research.

Based on the assumptions of the integrated model of enterprise competitiveness, table 3 proposes the assessment of the above-mentioned elements as presumed components of the competitiveness of a public hospital. In addition, the determinants of competitiveness affecting the improvement or deterioration of a particular component of enterprise competitiveness were evaluated.

The analysis presented in the table 3 is a preliminary attempt to test the possibility of applying the integrated enterprise competitiveness model to assess the competitiveness of a public hospital. A thorough analysis requires a detailed operationalization of commercial competitiveness assessment tools in the areas characterized above. In addition, the improvement methods indicated in the individual elements of the integrated competitiveness model point to the area of possible improvement actions in a public hospital.

\section{Discussion}

The regulatory and legal sphere, to a large extent, limits the possibility of managing public health care entities in Poland so as to increase their competitiveness, primarily by preventing the use of strategic management and flexible operational management. This is mainly due to the significant number of legal provisions and uncertainty in terms of how long they will remain in force as well as the prerequisites for contract application with the National Health Fund (NFZ). The introduction of changes in this respect and stable strategic prospects for management processes would be an impulse for undertaking innovative development initiatives. To a certain extent, the regulation of prerequisites for granting a contract for health care services provision is bound to affect 
the competitive potential of a public hospital, while the pro-quality regulations contribute to continuous improvement.

The question arises to what extent, in the current legal environment, the competitive environment can cause an increase in competitive behavior and whether public health care entities may be forced to take more effective actions. Such actions must embrace the fulfillment of health care needs and the implementation of all types of health care services regardless of their profitability. Another problem in this area still involves the valuation of health care services adopted by the NFZ (the valuation of services should be carried out based on a reliable cost account that takes into consideration the need for investment in human and material capital, which directly translates into improved competitive potential).

Parallel to adverse demographic trends, which affect the structure of both patients and health care workers, positive trends related to the development of medical and IT technologies are emerging. Accordingly, the questions arise not only about how to counteract threats, but also how to take advantage of the opportunities appearing in the environment of health care entities. Taking into account the medical and social objectives of hospitals, their managers should particularly strive to improve the management of financial resources, while maintaining the adequate quality of services provided (Wiercińska, 2015, p. 492). The ability of hospitals in making innovation which will have an impact on the achievement of hospital's competitive advantage will be affected (Tutik \& Arief, 2016). Hospitals willing to critically evaluate and change their operating structures which not only can increase productivity and decrease operating costs, but also are able to significantly improve the quality of patient care (Lee \& Clarke, 1992). Hospital is much more complex than other manufacturing organizations, since it undertakes medical and health responsibilities that deal with the lives of people (Priya \& Jabarethina, 2016).

The evaluation of hospital competitiveness is a dynamic, complex systems engineering (Lu et al., 2010). The assessment of the competitiveness of a public hospital must, to a certain extent, also address the quality of its relations with stakeholders. Hospitals can use the dynamic capabilities framework to achieve competitive advantage in today's difficult healthcare environment (Agwunobi \& Osborne, 2016).

Additionally, it should be emphasized that public organizations have the opportunity to obtain resources using a mixture of social persuasion and public pressure, while competition between them tends to be more focused on gaining competitive advantage in the area of effective use of resources and, as a result, acquiring a larger pool of limited public resources (Frączkiewicz-Wronka \& Szymaniec, 2013, p. 155).

\section{Conclusion}

The considerations presented in the article may encourage research on the competitiveness of a modern public hospital and, in practice, create conditions for 
its development in the future, although, as Rauch (2015) points out, the use of innovative initiatives in the transformation of health care can be problematic because people working in the sector need to change their mindset. It should also be pointed out that straightforward competitiveness, focused on financial performance at a cost of the health and life of patients, can pose a threat to the mission of organizations operating of the health care sector. The assessment of the presented research methodology in the context of its application in the public healthcare sector gives grounds to conclude that in the future it may be used to conduct research on the competitiveness of a public hospital. It should be mentioned that these tests should cover the entire activity of the examined hospital, taking into account, inter alia, the issue of complementarity of provided medical services.

\section{References}

Agwunobi, A., \& Osborne, P. (2016). Dynamic capabilities and healthcare: a framework for enhancing the competitive advantage of hospitals. California Management Review, 58(4). doi:10.1525/cmr.2016.58.4.141.

Barros, R., \& de Jesus Pacheco, D.A. (2016). Health services management: an approach for performance improvement. Revista geintec-gestao inovacao e tecnologias, 6(2).

Bielicki, R., \& Ciesielski, T. (2012). Strategiczna Karta Wyników jako narzędzie poprawy konkurencyjności jednostek medycznych. Zeszyty Naukowe Uniwersytetu Szczecińskiego: Studia i Prace Wydziatu Nauk Ekonomicznych i Zarządzania, 25.

Bossak, J., \& Bieńkowski, W. (2004). Międzynarodowa zdolność konkurencyjna kraju i przedsiębiorstw: wyzwania dla Polski na progu XXI wieku. Warszawa: SGH.

Bratnicki, M. (2000). Kompetencje przedsiębiorstwa: od określenia kompetencji do zbudowania strategii. Warszawa: Placet.

Eiriz, V., Barbosa, N., \& Figueiredo, J. (2010). A conceptual framework to analyse hospital competitiveness. The Service Industries Journal, 30(3). doi:10.1080/02642060802236137.

Flak, O., \& Głód, G. (2012). Konkurencyjni przetrwają: o przedsiębiorstwie, metodach badania konkurencyjności i twoich szansach na sukces rynkowy. Warszawa: Difin.

Flak, O., \& Glód, G. (2015). Features of Polish companies: results of the company competitiveness barometer 2014. Oeconomia Copernicana, 6(3). doi:10.12775/ оес.2015.024.

Frączkiewicz-Wronka, A., \& Szymaniec, K. (2013). Zastosowanie koncepcji RBV do pragmatyki funkcjonowania szpitali publicznych. Organization and Management, 5(158).

Głód, G. (2016). Uwarunkowania i pomiar przedsiębiorczości publicznej w jednostkach ochrony zdrowia. Warszawa: Difin. 
Goodman, J.C., Herrick, D.M., \& Musgrave, G.L. (2008). Jak uzdrowić stużbę zdrowia: raport o światowych systemach opieki zdrowotnej. Chicago-Warszawa: Fijorr Publishing.

Hass-Symotiuk, M. (Ed.). (2011). System pomiaru i oceny dokonań szpitala. Warszawa: Wolters Kluwer.

Kanownik, G. (2014). Znaczenie benchmarkingu w ksztaltowaniu konkurencyjności szpitali. Zeszyty Naukowe Uniwersytetu Szczecińskiego: Finanse, Rynki Finansowe, Ubezpieczenia, 65(802).

Kożuch, B. (2004). Zarządzanie publiczne: $w$ teorii i praktyce polskich organizacji. Warszawa: Placet.

Lee, J.G., \& Clarke, R.W. (1992). Restructuring improves hospital competitiveness. Journal of the Healthcare Financial Management Association, 46(11).

Li, L., \& Xia, L. (2013). Evaluation of hospital competitiveness in Jiangxi province based on the cluster analysis. In E. Qi, J. Shen, R. Dou (Eds.), The 19th international conference on industrial engineering and engineering management. Berlin: Springer. doi:10.1007/978-3-642-38427-1_131.

Lu, X., Li, L., \& Hua, C. (2010). Hierarchy analysis on three-level comprehensive hospital competitiveness evaluation in Jiangxi province based on rough set. In Z. Qihai (Ed.), 2010 International forum on information technology and applications. Kunming: IEEE. doi:10.1109/IFITA.2010.299.

Lu, Z., Wang, J. (2008). Establishment of the core factors for hospitals' competitiveness and their weighing method. In Q. Ershi, W. Jinfeng, S. Jiang (Eds.), Management innovation and industrial engineering for the rise of central China: the proceedings of the 15th international conference on industrial engineering and engineering management. Zhengzhou: Zhengzhou University.

Macuda, M. (2015). Rola benchmarkingu w pomiarze i ocenie dokonań szpitali. Prace Naukowe Uniwersytetu Ekonomicznego we Wroctawiu, 398. doi:10.15611/ pn.2015.398.29.

Majchrzak-Lepczyk, J., \& Bober, B. (2016). Selected aspects of the logistics network of public hospitals in the competitive market of health services. LogForum, 12(4). doi:10.17270/J.LOG.2016.4.6.

Obwieszczenie Ministra Zdrowia z dnia 10 listopada 2017 r. w sprawie ogłoszenia jednolitego tekstu rozporządzenia Ministra Zdrowia w sprawie świadczeń gwarantowanych z zakresu leczenia szpitalnego [Announcement of the Minister of Health of 10 November 2017 on the codification of the Regulation of the Minister of Health on the cover guaranteed in the area of hospital treatment] (Dz.U. 2017 poz. 2295) (Poland).

Olszewska, B., \& Piwoni-Krzeszowska, E. (2004). Partnerstwo z klientami szansą zwiększenia konkurencyjności przedsiębiorstw. In Z. Olesiński, \& A. Szplit (Eds.), Przedsiębiorstwo i region w zjednoczonej Europie. Kielce: AŚ.

Porter, M.E. (2007). Winning competitive strategies in today's shifting global marketplace. Retrieved 31.03.2019 from https://www.hbs.edu. 
Priya, G.D., \& Jabarethina, G. (2016). A study on sustainable competitive advantage by managing service quality at a multi speciality corporate hospital, Chennai. Prabandhan: Indian Journal of Management, 9(7). doi:10.17010/ pijom/2016/v9i7/97787.

Rauch, J. (2015). Disruptive entrepreneurship is transforming U.S. health care. Retrieved 31.03.2019 from https: / /www.brookings.edu.

Romaniuk, P., Holecki, T., \& Woźniak-Holecka, J. (2016). Using new instruments of clustering policy in the health care system: the case of Poland. Frontiers in Pharmacology, 7. doi:10.3389/fphar.2016.00177.

Rozporządzenie Ministra Zdrowia z dnia 21 września 2018 r. zmieniające rozporządzenie w sprawie sposobu ustalania ryczałtu systemu podstawowego szpitalnego zabezpieczenia świadczeń opieki zdrowotnej [Regulation of the Minister of Health of 21 Septemeber 2018 amending the regulation on the method of determining the flat-rate system of the basic hospital provision of health care services] (Dz.U. 2018 poz. 1812) (Poland).

Rozporządzenie Ministra Zdrowia z dnia 5 sierpnia 2016 r. w sprawie szczegółowych kryteriów wyboru ofert $\mathrm{w}$ postępowaniu w sprawie zawarcia umów o udzielanie świadczeń opieki zdrowotnej [Regulation of the Minister of Health of 5 August 2016 on specific criteria for the selection of tenders in proceedings on the conclusion of contracts for the provision of health care services] (Dz.U. 2016 poz. 1372) (Poland).

Stabryła, A. (2000). Zarządzanie strategiczne w teorii i praktyce firmy. Warszawa: PWN.

Tutik, A., \& Arief, M. (2016). Sustainable competitive advantage in general hospital industry. Advanced Science Letters, 22(12). doi:10.1166/asl.2016.8202.

Urbanowska-Sojkin, E., Banaszyk, P., \& Witczak, H. (2004). Zarządzanie strategiczne przedsiębiorstwem. Warszawa: PWE.

Wiercińska, A. (2015). Wykorzystanie benchmarkingu w zarządzaniu finansami szpitali na przykładzie województwa pomorskiego. Prace Naukowe Uniwersytetu Ekonomicznego we Wroctawiu, 399. doi:10.15611/pn.2015.399.49.

Ziębicki, B. (2014). Efektywność organizacyjna podmiotów sektora publicznego. Kraków: UE.

\section{Acknowledgements}

Author contributions: author has given an approval to the final version of the article.

Funding: this research was funded by the University of Economics in Katowice, Faculty of Economics, Department of Entrepreneurship and Innovation Management statutory sources.

Note: the results of this study were presented at 10th International Conference on Applied Economics Contemporary Issues in Economy (June 27-28, 2019, Torun, Poland). 


\section{Appendix}

Table 1 .

\section{Selected requirements for the provision of health care services in the field of vascular surgery}

\begin{tabular}{|c|c|c|}
\hline \multicolumn{2}{|c|}{ Area of service provision } & Characteristics of selected requirements \\
\hline \multirow{5}{*}{ 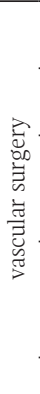 } & doctors & $\begin{array}{l}\text { - equivalent of at least } 2 \text { full-time positions (it does not include a duty shift) - a vas- } \\
\text { cular surgery specialist }\end{array}$ \\
\hline & $\begin{array}{l}\text { organization } \\
\text { of service provision }\end{array}$ & $\begin{array}{l}\text { - providing 24-hour medical care on all days of the week (it cannot be shared with } \\
\text { other hospital wards) }\end{array}$ \\
\hline & medical equipment & $\begin{array}{l}\text { - at the venue of providing services: (1) a colored-Doppler ultrasonography, (2) a car- } \\
\text { diac monitoring } \\
\text { - on the premises - a vascular X-ray machine }\end{array}$ \\
\hline & other requirements & $\begin{array}{l}\text { - a diagnostic and treatment room — at the venue where services are provided } \\
\text { - operating block - in the location } \\
\text { - provision of endovascular treatment }\end{array}$ \\
\hline & provision of tests & - vascular X-ray \\
\hline \multirow{13}{*}{ 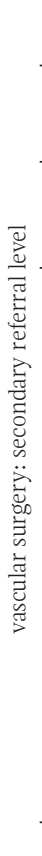 } & doctors & $\begin{array}{l}\text { - equivalent of at least } 3 \text { full-time positions (it does not include a duty shift) - a vas- } \\
\text { cular surgery specialist }\end{array}$ \\
\hline & $\begin{array}{l}\text { organization } \\
\text { of service provision }\end{array}$ & $\begin{array}{l}\text { - 24-hour medical care on all days of the week - a vascular surgery specialist or } \\
\text { a physician during specialization in the field of vascular surgery (it cannot be shared } \\
\text { with other hospital wards) }\end{array}$ \\
\hline & medical equipment & $\begin{array}{l}\text { - at the venue of providing services: (1) a C-arm X-ray system, (2) colored-Doppler } \\
\text { ultrasonography, (3) a cardiac monitoring } \\
\text { - on the premises - a stationary vascular X-ray machine }\end{array}$ \\
\hline & \multirow{9}{*}{ other requirements } & $\begin{array}{l}\text { - a documented number of performed open surgeries in all vascular areas on an annual } \\
\text { basis: at least } 450 \text { operations (including: carotid arteries, arteries exiting the aortic } \\
\text { arch, aorta, lower limb arteries, dialysis fistulae, myocardiac bridges), confirmed by } \\
\text { a regional consultant in the field of vascular surgery }\end{array}$ \\
\hline & & $\begin{array}{l}\text { - a documented number of performed endovascular operations on an annual basis: } \\
\text { a minimum of } 300 \text {, including at least } 40 \text { thoracic and/or abdominal stent grafts, } \\
\text { confirmed by a regional consultant in the field of vascular surgery }\end{array}$ \\
\hline & & $\begin{array}{l}\text { - a documented minimum of } 50 \text { performed operations on an immediate or urgent ba- } \\
\text { sis, confirmed by a regional consultant in the field of vascular surgery }\end{array}$ \\
\hline & & - a diagnostic and treatment room — at the venue where services are provided \\
\hline & & - an anaesthesiology and intensive care ward — on the premises \\
\hline & & - an operating suite — on the premises \\
\hline & & $\begin{array}{l}\text { - providing a } 24 \text {-hour nursing duty within the operating suite - equivalent to a min- } \\
\text { imum of } 2 \text { full-time jobs }\end{array}$ \\
\hline & & - providing endovascular treatment \\
\hline & & - ensuring the provision of services $24 / 7$ \\
\hline & provision of tests & - vascular X-ray \\
\hline
\end{tabular}

Source: Announcement of the Minister of Health on the codification of the Regulation of the Minister of Health on the cover guaranteed in the area of hospital treatment (2017). 
Table 2.

The selection criteria for tenders submitted in the contracting proceedings for the provision of health care services in the field of vascular surgery

\begin{tabular}{|c|c|c|}
\hline Criterium & Category & Selected requirements under evaluation \\
\hline \multirow{3}{*}{ quality } & staff & $\begin{array}{l}\text { - } 24 \text {-hour medical care on all days of the week provided by } 2 \text { doctors, includ- } \\
\text { ing a vascular surgery specialist } \\
\text { - equivalent of a minimum of } 2 \text { full-time jobs - a nurse who completed } \\
\text { a qualifying course in the field of surgical nursing }\end{array}$ \\
\hline & $\begin{array}{l}\text { provision of se- } \\
\text { lected services }\end{array}$ & $\begin{array}{l}\text { - a share of preventive hospitalization in the last } 12 \text { months - up to } 15 \% \text { of all } \\
\text { hospitalizations } \\
\text { - performance of at least } 50 \% \text { of the listed specialist procedures in the last } \\
12 \text { months } \\
\text { - treatment at least } 50 \% \text { of the diagnosed ICD-10 in the last } 12 \text { months }\end{array}$ \\
\hline & $\begin{array}{l}\text { other prereq- } \\
\text { uisites }\end{array}$ & $\begin{array}{l}\text { - the ward provides specialized training for doctors conducted by an entity } \\
\text { listed as an accredited specialist training provider in the field corresponding } \\
\text { to the scope of services covered by the subject of the proceedings }\end{array}$ \\
\hline \multirow{4}{*}{$\begin{array}{l}\text { comprehensive } \\
\text { coverage }\end{array}$} & $\begin{array}{l}\text { out-patient } \\
\text { clinics/wards/ } \\
\text { medical facilities } \\
\text { and laborato- } \\
\text { ries/surgeries }\end{array}$ & $\begin{array}{l}\text { - a pharmacy, an anesthesiology and intensive care ward } \\
\text { - a minimum of } 2 \text { intensive care beds with dedicated nursing care } \\
\text { - an interventional radiology clinic }-24 \text { hours on the premises } \\
\text { - a tenderer performs a contract for the treatment of vascular diseases } \\
\text { in the hospital clinic }\end{array}$ \\
\hline & $\begin{array}{l}\text { examination } \\
\text { and treatment } \\
\text { on a } 24 \text {-hour } \\
\text { basis }\end{array}$ & $\begin{array}{l}\text { - angiography, endoscopic examination, computed tomography, magnetic } \\
\text { resonance }\end{array}$ \\
\hline & accessibility & $\begin{array}{l}\text { - admissions of emergency assistance recipients at a level of over } 40 \% \\
\text { in the last } 12 \text { months }\end{array}$ \\
\hline & price & - proposed by a tenderer \\
\hline
\end{tabular}

Source: Regulation of the Minister of Health on specific criteria for the selection of tenders in proceedings on the conclusion of contracts for the provision of health care services (2016). 
Table 3.

The evaluation of the elements of the integrated model of enterprise competitiveness in the process of the assessment of the competitiveness of a public hospital

\begin{tabular}{|c|c|c|}
\hline $\begin{array}{c}\text { Element } \\
\text { of the inte- } \\
\text { grated model } \\
\text { of enterprise } \\
\text { competitive- } \\
\text { ness }\end{array}$ & $\begin{array}{c}\text { Specific } \\
\text { dimensions }\end{array}$ & $\begin{array}{c}\text { Reference to the competitiveness } \\
\text { of a public hospital }\end{array}$ \\
\hline
\end{tabular}

Adequate financial resources to provide cost-intensive health care services to ensure financial liquidity. Adequate finance investment activity and ensuring optimal sources of its financing. The possibility of performing new health care procedures, which will be unprofitable in the initial period
Determinants affecting the improvement or deterioration in the competitiveness of a public hospital

With regard to improving financial potential, it is possible to apply elements of modern financial management, in particular controlling tools. Investment activities that reduce an entity's operating costs in the long term. Performing unlimited and profitable health care procedures. In the area of decreased financial potential, it is possible to indicate an insufficient pricing of health care procedures and increased costs resulting in deteriorating profitability.

Adequate internal reporting and reporting
to the public payer. Information flow
in the hospital that enables the adequate
coordination of activities and timely provi-
sion of services.

With regard to improving reporting, the computerization of a hospital, the appropriate development of processes and organizational structures, and effective communication with patients should be indicated. The failure to implement these solutions significantly reduces information potential.

The possibility of introducing new health care procedures contributing to the adequate status of a hospital. Investment in medical equipment and staff training in order to implement innovative solutions in the field of health care services.

competitive potential
Improved innovation potential can be achieved through the consistently implemented development strategy of a hospital paired with the deliberate management of the innovation implementation process. This is a key component of a hospital's competitive potential in the context of improving or maintaining competitive position.

Improvement measures should involve the implementation of an appropriate human resource strategy that aims to maintain and develop the competences of medical staff. The basic factor lowering competitive potential in this area is the situation on the labor market and the difficulty in ensuring competitive wage conditions.

Ensuring the accessibility of services provided together with complementary accompanying services and the ability to perform an appropriate number of health care procedures, including the required specification of hospitalized persons.

The improvement in organizational potential can be achieved through comprehensive development of services, which is perceived as a comprehensive process (diagnosis, treatment, consultation, rehabilitation, prevention). Conducting fragmented services can strategically lower organizational potential.

The possession of adequate equipment and infrastructure contributes to the improvement in material potential and the consistently implemented investment strategy. Inactivity in this area diminishes potential and even takes away the ability to conduct medical activities.

The implementation of new medical technologies is a primary condition for being able to stay in the market of highly specialized health care services. 


\begin{tabular}{|c|c|c|c|}
\hline $\begin{array}{c}\text { Element } \\
\text { of the inte- } \\
\text { grated model } \\
\text { of enterprise } \\
\text { competitive- } \\
\text { ness }\end{array}$ & $\begin{array}{l}\text { Specific } \\
\text { dimensions }\end{array}$ & $\begin{array}{l}\text { Reference to the competitiveness } \\
\text { of a public hospital }\end{array}$ & $\begin{array}{l}\text { Determinants affecting the improvement } \\
\text { or deterioration in the competitiveness } \\
\text { of a public hospital }\end{array}$ \\
\hline \multirow{3}{*}{$\begin{array}{l}\text { strategy } \\
\text { of the com- } \\
\text { petition }\end{array}$} & price-related & The price proposed by a hospital. & $\begin{array}{l}\text { The prerequisites proposed by the public pay- } \\
\text { er and the possibility of using the economies } \\
\text { of scale on the side of the hospital. }\end{array}$ \\
\hline & $\begin{array}{l}\text { quality- } \\
\text { related }\end{array}$ & $\begin{array}{l}\text { Evaluation of qualitative indicators } \\
\text { in the competition procedure. }\end{array}$ & $\begin{array}{l}\text { A public hospital accreditation and integrated } \\
\text { quality management systems. }\end{array}$ \\
\hline & market niche & $\begin{array}{l}\text { The capacity for performing specialized } \\
\text { medical procedures. }\end{array}$ & $\begin{array}{l}\text { The experience effect to the advantage or } \\
\text { disadvantage of a hospital. The problem with } \\
\text { the profitability of small-scale activity due } \\
\text { to financial outlays and staffing constraints. }\end{array}$ \\
\hline \multirow{4}{*}{$\begin{array}{l}\text { competitive } \\
\text { advantage }\end{array}$} & $\begin{array}{l}\text { product- } \\
\text { based }\end{array}$ & The scope of medical procedures. & $\begin{array}{l}\text { Conducting activity in the scope required by } \\
\text { the payer with a sufficient number of histori- } \\
\text { cally performed services. }\end{array}$ \\
\hline & price-based & $\begin{array}{l}\text { A competitive price compared to other } \\
\text { service providers. }\end{array}$ & $\begin{array}{l}\text { Prerequisites proposed by the public payer } \\
\text { and adequate management of hospital costs. }\end{array}$ \\
\hline & $\begin{array}{l}\text { distribution- } \\
\text { based }\end{array}$ & Attractive location. & $\begin{array}{l}\text { The location of a hospital in the context } \\
\text { of maps of health needs and the adjustment } \\
\text { of a hospital's profile to changes in this area. }\end{array}$ \\
\hline & $\begin{array}{l}\text { promotion- } \\
\text { based }\end{array}$ & It does not formally exist. & $\begin{array}{l}\text { The adequate organization of services, short } \\
\text { waiting time for an appointment, access } \\
\text { to complementary services and a hospital's } \\
\text { reputation may be perceived by patients as } \\
\text { a specific promotional advantage. }\end{array}$ \\
\hline \multirow{2}{*}{$\begin{array}{l}\text { competitive } \\
\text { position }\end{array}$} & market share & $\begin{array}{l}\text { Possible to measure based on information } \\
\text { published by the public payer. }\end{array}$ & $\begin{array}{l}\text { Possible to increase primarily in the situation } \\
\text { when other entities lose a contract or } \\
\text { the payer increases the value of a contract. }\end{array}$ \\
\hline & $\begin{array}{l}\text { financial } \\
\text { performance }\end{array}$ & Assessment based on financial statements. & $\begin{array}{l}\text { Doubts whether financial performance } \\
\text { is a primary criterion for the assessment } \\
\text { of a public hospital. }\end{array}$ \\
\hline \multirow[b]{2}{*}{$\begin{array}{l}\text { competitive } \\
\text { platform }\end{array}$} & $\begin{array}{l}\text { micro } \\
\text { environment }\end{array}$ & $\begin{array}{l}\text { Suppliers, recipients, entry and exit barri- } \\
\text { ers, substitute products, competitors. }\end{array}$ & $\begin{array}{l}\text { The pricing policy of suppliers, the behavior } \\
\text { of other employers on the labor market, } \\
\text { the possibility of using alternative treatment } \\
\text { strategies, a limited opportunity for a quick } \\
\text { entry as a provider of highly specialized } \\
\text { health care services. }\end{array}$ \\
\hline & $\begin{array}{l}\text { macro } \\
\text { environment }\end{array}$ & $\begin{array}{l}\text { - international } \\
\text { - cultural } \\
\text { - demographic } \\
\text { - economic } \\
\text { - legal } \\
\text { - technological }\end{array}$ & $\begin{array}{l}\text { Legal conditions (stable solutions determining } \\
\text { the functioning of public hospitals); the pos- } \\
\text { sibility of increased health care expenditure } \\
\text { in Poland; the dynamics of demographic } \\
\text { changes; the implementation cycle of new } \\
\text { medical technologies. }\end{array}$ \\
\hline
\end{tabular}

\section{Source: Own preparation.}




\section{Scheme 1 .}

The integrated model of company competitiveness

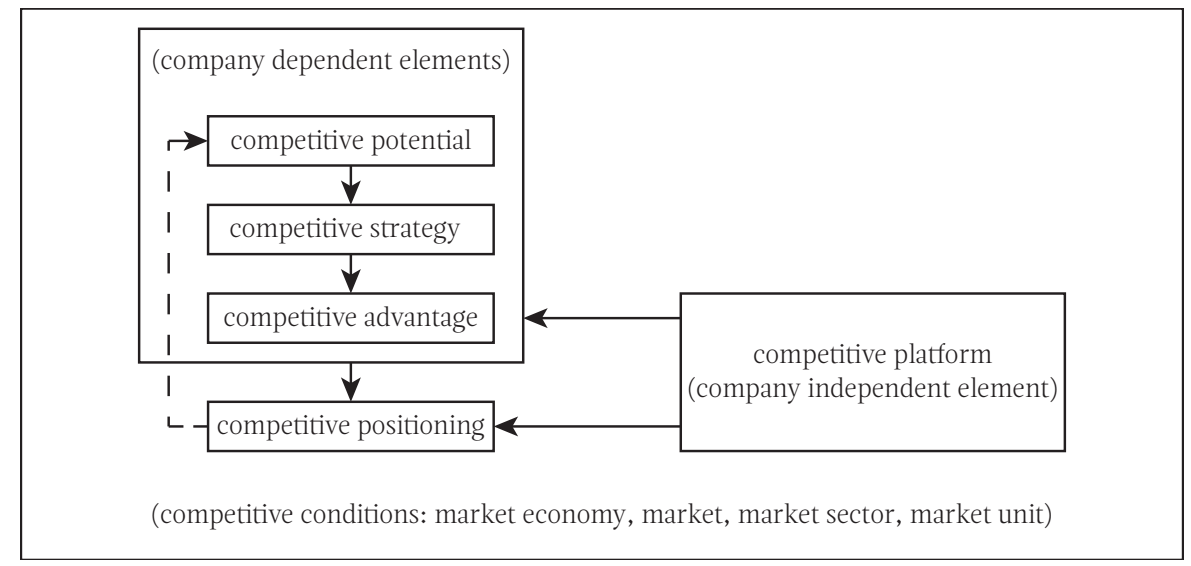

Notes:

Solid line denotes short-term actions, dashed line means long-term actions.

Source: Flak \& Głód (2015, p. 122). 